\title{
間歇性跛行症例卜ソ 考察
}

\author{
京都府立醫科大學內科學教空 (主任 舘石教授) \\ 助手山本克起・駒井保彦
}

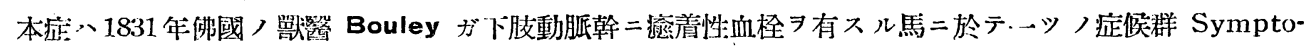
men Komplex トシテ命名シタモノデ，1858年= Charcot ガ始メテ人間二於テ墢見シ，其ノ後Erb等ニ ヨツテ最エ詳細ニ報告サレタモノデアル。

症例

㭧者 狗○吉○郎 今 33歲 農業

昭和 27 年 9 月 22 日人院

主訴 步行障碍

家族史 父八胃攄張二テ死亡シ母八腹膛炎ニョリ死亡シテ居ル. 兒 4 名健在スル。

現病前既往 梅毒, 糖尿病等無ク特記スベキモノナシ.

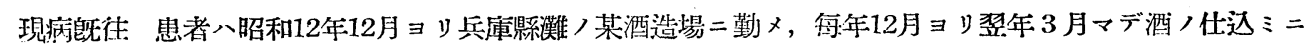
從事シテ居タ.

其ノタメ $0{ }^{\circ} \mathrm{C}$ 近クノ冷水中二(約 2 時間) 足习浚スコトガ多カッタ. 柆13年冬モ同樣ノ仕事タシテ居タガ ソ 頃ョリ時々走儿場合二下肢二疼痛习感ジタガアマリ氣二セズ働イテ居タ.

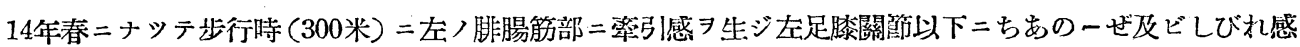
$\exists$ 覺エ逐二跛行 $习$ 來ス樣ニナッタ.

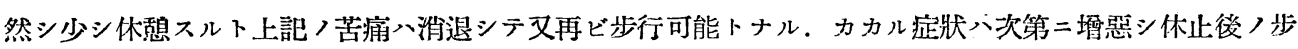
行距離モダンダン短クナッテ來タ.

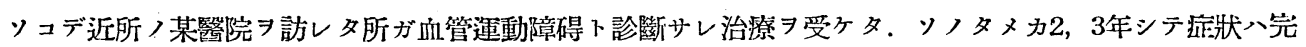
全デハナイガ殆ンド輕快シ苦痛モアマリ感ジナクナッタ.

所ガ昨年春頃 $コ$ 再ビ步行困難

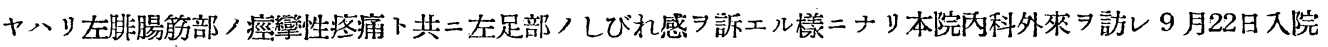
シタ.

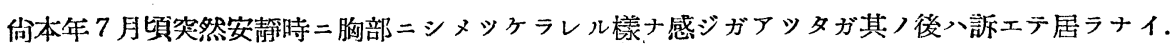

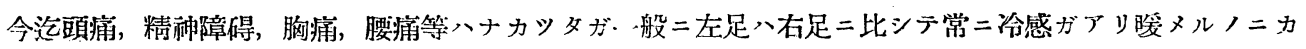
ナリ時間ガカカルト云ウ.

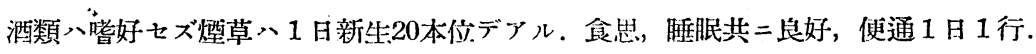

\section{入院時現症}

體格中等度, 骨格良好, 㮡誉ヤヤ衰エテ居ル。意識障碍ナク元氣デアル．

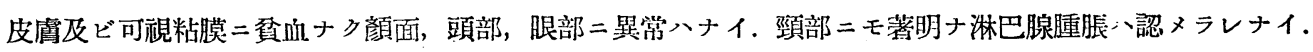
舌ハ濕閏シ舌苔ハナク，咽頭部ハ正常デ屚桃腺〉腫脹モナイ。

脈搏入 1 分間78，整調デアルガ可成り硬り緊張入佳良デアル。

心濁曋界八稍々左二撗大，心音八純デアルガ第二肺動胍音，第二大動脈音ガ艺進シテ居ル。

肺ニ八他覺的二異常习認メナイ。

腹部本坦, 腹壁緊張異常ナク自登痛, 壓痛等ナク異常抵抗モ證明シナイ。

肝，脾，筲八解知セで。 
手二輕度ノ震聝頁

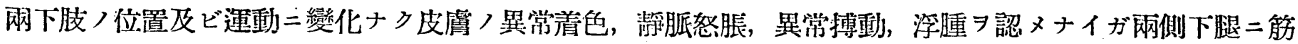

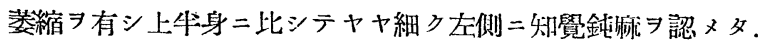

下肢表在性動脈ノ搏動 $\ni$ 檢スル二足背動脈ノ搏動ハ右側入輕度二觸知スルガ左側、全ク觸知セズ，左側股 動胍〉搏動、明二右側ヨリ弱ク時ニ觸知シナイコトェアル。

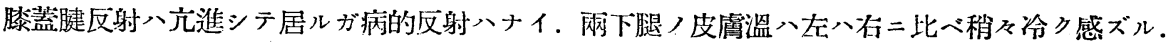

\section{臨床諸檢查成績}

1）血液所見 赤血球數 441 万, 白血球數 7200 , 血色絜 $85 \%$ (ざーりーう, 血色素係數 0.96 , 白血球百分率

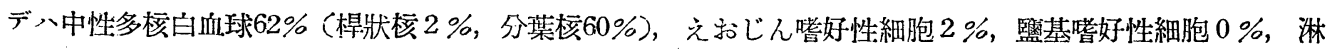
巴球 $32 \%$ (大淋巴球 $8 \%$ ，小淋巴球 $24 \%$ )，單核球 $4 \% ，$ 血球泥降速度 1 時間 $11 \mathrm{~mm} ， 2$ 時間 $20 \mathrm{~mm}$ ，中等價 10.5. $\mathrm{mm}$

2）血清わつせるまん反隹 陰性.

3) 電氣心動圖 異常

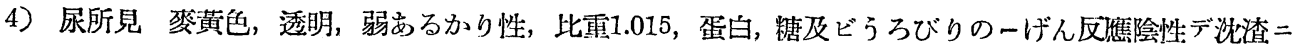
モ暴常所見ハナイ.

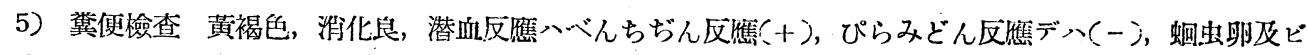
鞭虫卵ガカナリ見ラレタ、

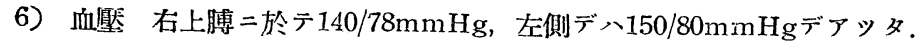

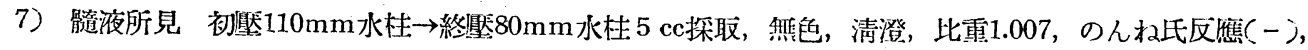

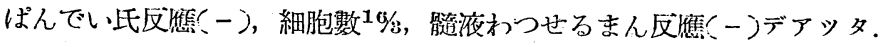

8) 步行試驗 正常步行速度デ約 $120 \mathrm{~m}$ ( 2 分) ニテ在腓腸筋部ノ輕痛

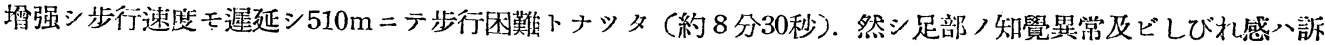
エテ嵓ナイ.

9）胸部X線像 心臟所見トシテハ大動脈弓部ハ正常デ動脈硬化ノ如キ像ハ見ラレズ，心臟ノ肥大モ認メ ラレナカッタ.

肺所見ハ正常デアッタ.

10) 藥郊試驗 あどれなりん試驗 (第 1 棐)，びろかるぴん試驗 (第 2 表)，あとろぴん試驗 (第 3 表) 7

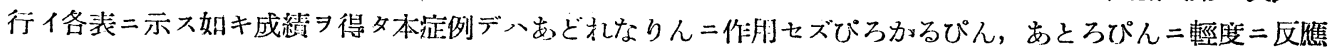
シタェノト思ワレル。

11）MosKowicz 氏試驗 大腿部 $习$ 驅而帶 $テ 5$ 分間緊搏シ解除後 ヨ檢シタ.

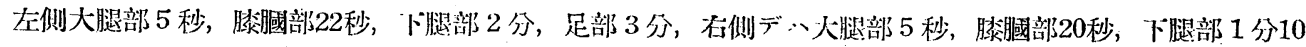

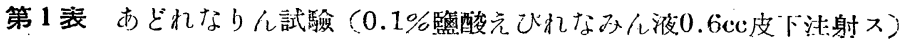

\begin{tabular}{|c|c|c|c|c|c|c|c|c|c|c|c|c|}
\hline \multicolumn{3}{|c|}{ ( 時 間 } & Vor & 5 & 30 & 15 & 20 & 30 & 40 & 50 & 60 & \multirow{2}{*}{$\frac{\text { 制定 }}{-}$} \\
\hline 血 & 壓 & 圥 進 & $150 / 80$ & $152 / 87$ & $160 / 90$ & $157 / 90$ & $153 / 85$ & $150 / 80$ & $148 / 80$ & $150 / 80$ & $\mid 150 / 82$ & \\
\hline 脈 & 搏 & 增 加 & 82 & 86 & 88 & 84 & 86 & 82 & 82 & 82 & 82 & - \\
\hline 副 & & 心悸元進 & \pm & + & \pm & \pm & 土 & \pm & \pm & - & - & \\
\hline 症 & & 反射元進 & - & - & - & - & - & - & - & - & - & - \\
\hline 姃 & & 顫 & + & + & + & + & + & + & + & + & + & - \\
\hline 狀 & & 呼吸頻數 & 18 & 18 & 18 & 20 & 18 & 18 & 16 & 18 & 18 & \\
\hline
\end{tabular}


第 2 表 びろかるびん試驗（0.1\%びろかるびん液0.6cc皮下注射ス）

\begin{tabular}{|c|c|c|c|c|c|c|c|c|c|c|c|}
\hline \multicolumn{2}{|c|}{ (時 間 } & Vor & 5 & 10 & 15 & 20 & 30 & 40 & 50 & 60 & 制定 \\
\hline \multirow{2}{*}{$\begin{array}{l}\text { 流 } \\
\text { 流 }\end{array}$} & 涎 (ccj & & 15 & 28 & 25 & 13 & 26 & 28 & 20 & 15 & + \\
\hline & 汗 & + & + & + & + & + & + & \pm & \pm & \pm & + \\
\hline \multirow{3}{*}{$\begin{array}{l}\text { 副 } \\
\text { 症 }\end{array}$} & 胒摶坦加 & 82 & 84 & 98 & 100 & 88 & 82 & 76 & 74 & 72 & \\
\hline & 顏面發赤 & \pm & + & + & + & + & + & + & \pm & - & - \\
\hline & 腹痛 & - & - & - & - & - & - & - & - & - & \\
\hline 狀 & 尿澺頻數 & - & - & - & - & - & - & - & - & - & \\
\hline
\end{tabular}

第3表 あとろぴん試驗(0.1\%あとろびん液0.6cc伎下注射入)

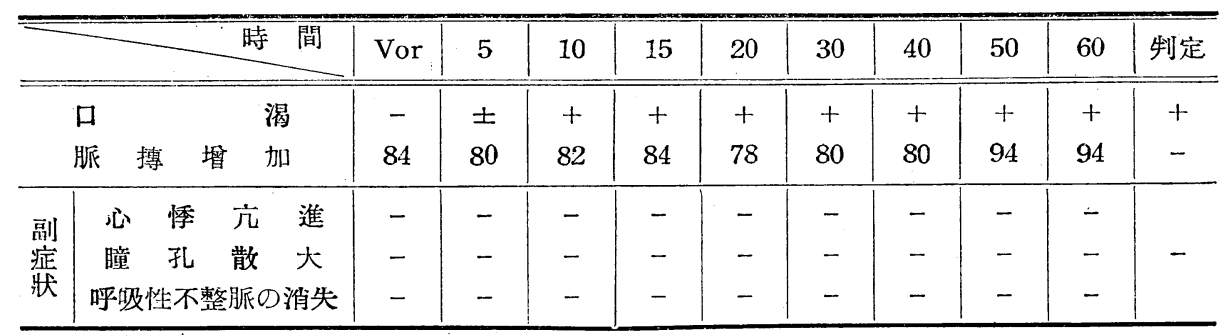

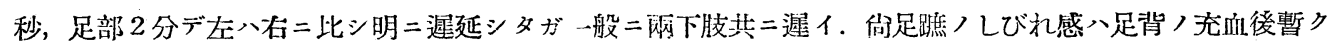
シテ沙退シタ。

12）耐糖力試驗 ぶどう糖50g ヨ溶液トシ負荷シタガ 1 時間, 2 時間, 3 時間後ノ尿二糖ヨ認メズ正常デ アッタ.

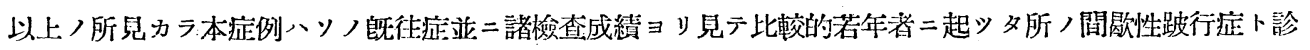
斷サレル。

\section{成因的考察}

本症‥般ニ血管ノ變化ニョッテ起ルモノト考エラレル。ソノ中デモ動脈ノ硬化が最モ重要ナ因子トナル ガ, 又下肢動脈，血栓或・動胍瘤等ニヨル血行障碍ニョッテモ本症が惹起サレル事がアル。

又神經疾患性素因 Neuropathische Diathese ガ本症ノ發現下密接ナ關係ガアルト云ワレテイル(oppen-

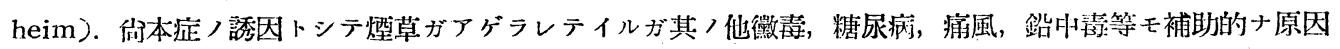
トナリ得ル。

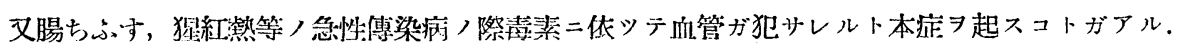

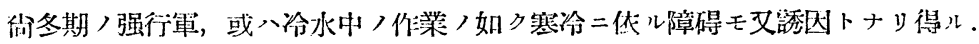

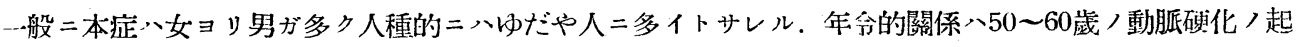
ル時期ニ多イガ又屡々若年者二モ起儿。

\section{症候}

臨床的ニハソノ主ナル症候ハ步行障碍デアルガ其ノ程度ハ大同小黑デ而モ安静時ニメ殆ンド健康者卜變ル 事ハナイ.

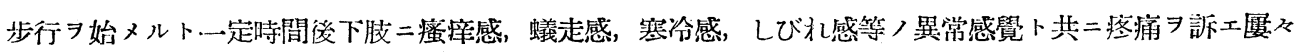

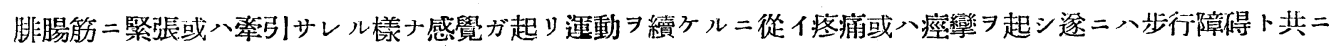
血管湩動障碍起り愿々足背, 足趾等八蒼白トナリ又ちむのーぜヨ呈スル.

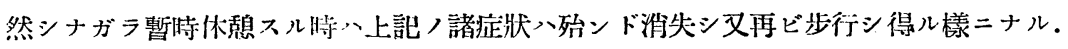


ソノ休款時間入通常長クナク2〜3分, 10分, 20分位デアル。

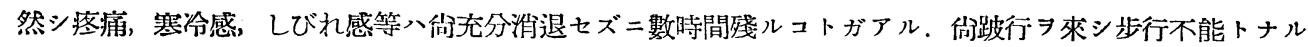
迄八時間八症狀二依り又人二依ツテ異ルガ步行 ヨ繰り返ス程上記症狀ハ早ク現レル樣ニナリ又長ク休マネバ ナラナクナル。

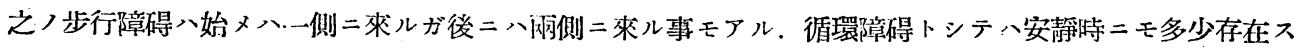

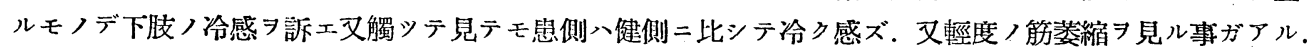

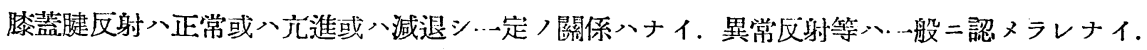

他覺的症候トシテ診斷時二八最モ特有ナノ八下肢動脈及ビ其ノ脈搏ノ異常デアル。郎チ患側ノ血管壁入硬

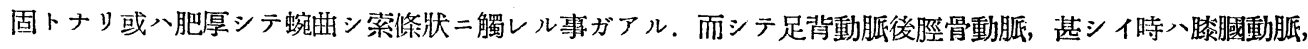
股動胍等ノ胍搏入一般二微弱デ時ニ八全》解レナイ、特二足背動胍二於テ著明デアル。

血管撮影 Vasographie ヨ行ウト屡队動脈硕化症〉所見ガ見ラレル。然シ乍ラ又血管二八器貿的二全ク異

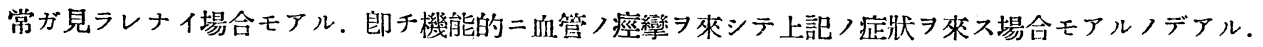

從ツテ本症ニ八神經性素因ガ又大二關係スルモノト思ワレル．何レうセヨ運動時二八下肢血管二生理學上

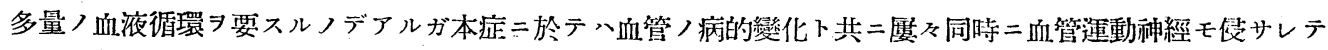

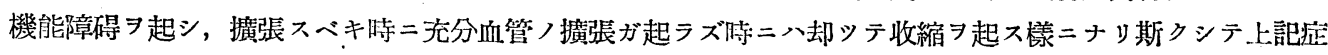

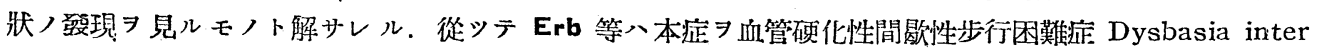
mittens angiosclerotica ト云ッテ居ル。

倘本症デ 八患側ノ脚ヨ高ク上ゲルト足ガ蒼白トナリ，下ゲルト充血ヨ來ス樣ニナル．此、 Gold flam's

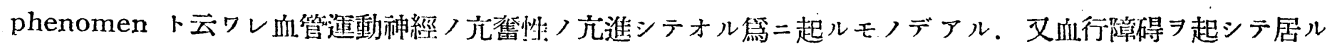

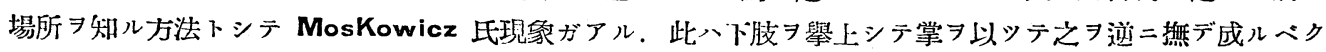

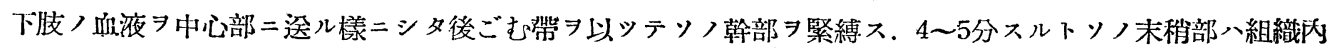

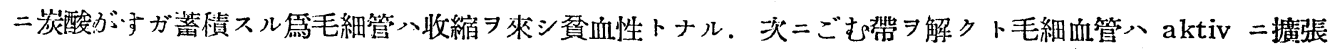
シテ動胍血ヨ受ヶスレルノデ皮膚二八自動的充血 aktive Hyperämie ヨ來ス. 正常ノ場合二八此ノ充血、 㨁チニ全部二起ルガ動脈二疾㭧ガアル時ニハリノ反應性充血 reaktive Hyperämie ヨ起スコトガ退ク特ニ

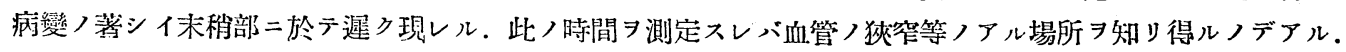
本症例二於テモ左側八右側二比シテ反礁性充血 ヨ起スコトガ退カッタ.

以上:述ベタト同樣ナ病變入同時二合併症トシテ脚以外ノ部分二モ見ラレル事ガアル。畐藏ノ冠狀動脈二病 變ガアル時二八狹心症 Angina Pectoris ノ弡作ヨ起スガ此レハ偝ハバ心臟ノ intermittierendes Hinken トモ云エル．本症患者妿既往症二於テ・一度胸部ニ締メッァラレル樣ナ感ジガアッタト訴エテ居ルガ恐ラク此 ノタメデアロウ.

腹部大動脈及ビンノ分枝二硬化アル時二八大食シテ $2 \sim 3$ 時間後郎チ消化ノ最モ盛ンナ時期二突然臍部二激

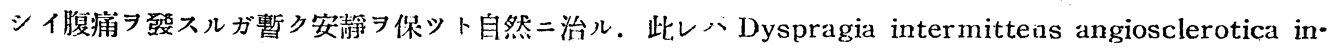
testinalis (Ortner) ト云ワレル。

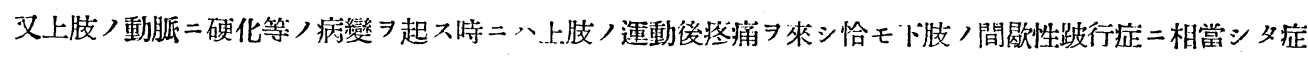

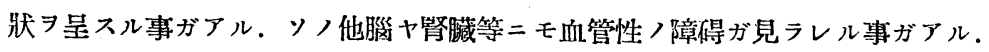

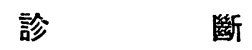

既往症並ビ二臨床的症候ニョク注意スレバ診斷ハ容易デアル。他覺的,二最モ特有ナノ八下肢動脈殊二足背 動脈ノ脈搏ガ全ク觸レナイカ觸レ難イ事デアル. Goldflam 氏現象, MosKowicz 氏現鸟等モ本症ノ補助的 診斷法トシテ意義ガアル。

本症卜鑑別 7 要スル類似ノ疾患トシテハ次ノモノガアル。

1) れいのう氏病

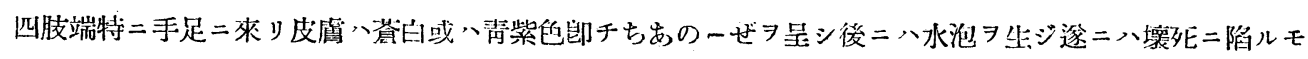




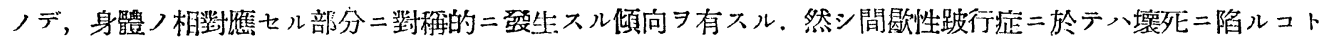
ハナイ.

2) 特發性朌瘨

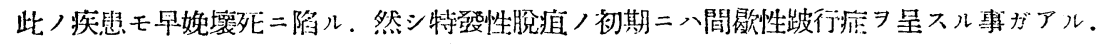

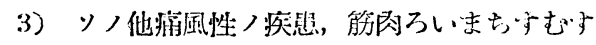

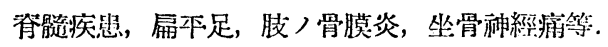

コレ等八既往症並二夫々ノ症俣特二步行障碍ノ起り方, 下肢動胍ノ胍搏等二注意スレバ容易二本症卜鑑別 セラレル.

\section{治 療}

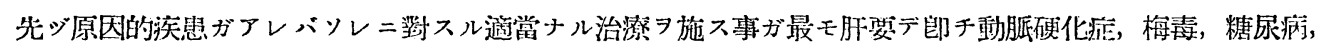

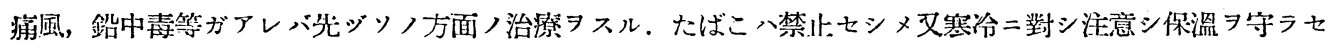
ル.

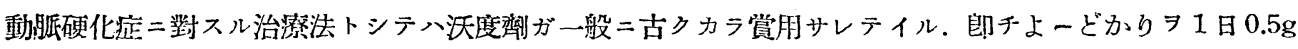

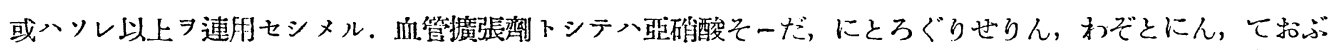
ろみん，扣いふいりん，岕ぐりん等为用イ，又時=ぢうれちんモ用イラレル。

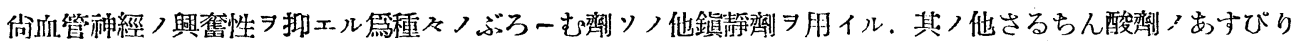
んヨ炜イルト効果ガアルト云ウ人モアル.

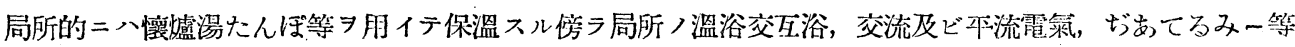

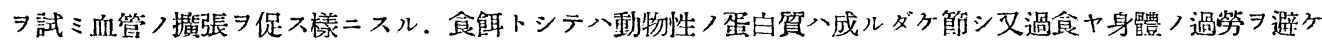
ル樣ニスル。

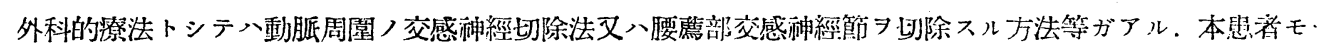
近ク外科的治潦习受々ル预定デ內科的ニハ殆ンド治源ヨ行ワナカッタ.

結語

要スルニ本症，比較的若年者二來夕間歇性跛行症ニシテ特二左下肢二著明デアル．

原因トシテハ既往痁二於テ下肢习長時間冷水中二漫ス作業二從事シテオッタ事ガ本症發現ノ要因トナッタ

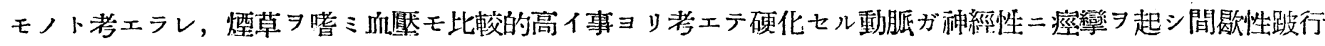
症习惹起シタモノト思ワレル。

擱筆後ニ當リ恩師舘石叔敎授ノ御愁篤ナル御校閲 7 感謝致シマス.

\section{主 要 文 献}
1) 加藤豊治郎：診斷卜治療，22兊，257 (1935).
2) 山田欽 : 東京醫事新誌, 3018號 (1937).

3）響場守三 : 醫事新聞，637，639，640，641，642 (1903)

4) 吳健, 坂本恒雄 : 内科㫪, 上卷.

5) 寡下俊一：日本循環器病學，2尞 (1936).

6) 八牧力雄: 日本外科寶函，20卷，2號 (1943).

7) 盛彌湱男 : 臨講, 37卷 (1933).

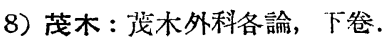




\section{The consideration upon a case of claudicatio intermittens}

By

\section{Yoshioki Yamamoto and Yasuhiko KomaI}

From Department of Internal Medicine, Kyoto Prefectural Medical University (Director: Prof. S. Tateishi)

As we have met with a case of Claudicatio intermittens in a fairly young man which occurred remarkably on the lower limbs, in particular, on the left lower limb, we report it here summarized as follows:

In anamnesis this case is to be considered mainly due to the work which required to have his lower limbs immersed in the cold waters for a long time.

And, judging from his fondness of smoking and his pretty high blood-pressure, we consider that sclerosed arteries, activating nervous cramps, caused Ciaudicatio intermittens.

\section{One case of Recklinghausen's disease which has a profund hereditary factor in his family.}

By

\section{Katsumi SHIMAdA and Eizaburo KONISHI.}

Department of Medicine, Kyoto Pref. Med. University (Director: Prof. S. 'Tateishi, M.D.)

We experienced a case of a 18 year-old man seized with Recklinghausen's disease which has a profound hereditary factor in his family.

It runs as following:

1) We found skin- ard nerve-tumors, brown pigment specks and one angioma in his skin.

2) On blood examination we found relative lymphocytosis and monocytosis, and an insignificant increase of $\gamma$-globuilin in serum.

3) This patient is most inferior and his similarly ill father and two brothers are also inferior mentally.

4) The hereditary type of Recklinghausen's disease in this patient's family is simple and dominant.

This patient's lineage :

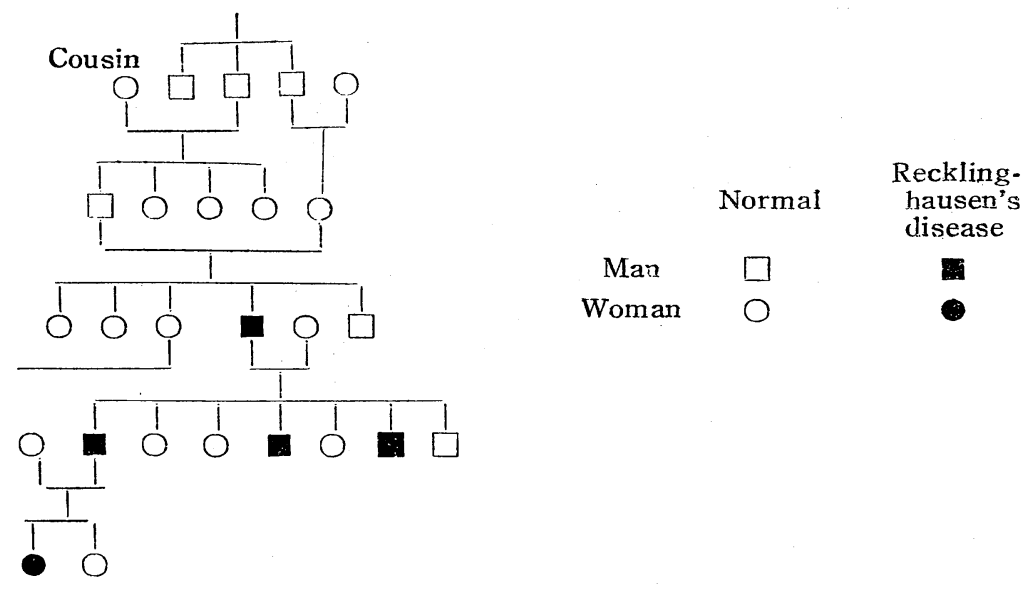

Vol. 28 No. 12 